Braz. J. Vet. Parasitol., Jaboticabal, v. 28, n. 1, p. 33-39, jan.-mar. 2019

Doi: https://doi.org/10.1590/S1984-296120180095

\title{
Microscopic alterations in Fasciola bepatica from sheep treated with albendazole
}

\author{
Alteraçóes microscópicas em Fasciola hepatica de ovelhas tratadas com albendazol \\ Milena Batista Carneiro ${ }^{1}$; Barbara Rauta Avelar²; Anderson Barros Archanjo ${ }^{3}$; Isabella Vilhena Freire Martins ${ }^{4 *}$ (1); \\ Louisiane de Carvalho Nunes ${ }^{5}$ Fabio Barbour $\operatorname{Scott}^{6}$
}

\begin{abstract}
${ }^{1}$ Programa de Pós-graduaçáo em Ciências Veterinárias, Universidade Federal Rural do Rio de Janeiro - UFRRJ, Seropédica, RJ, Brasil
${ }^{2}$ Programa de Pós-graduação em Ciências Veterinárias, Universidade Federal do Espírito Santo - UFES, Alegre, ES, Brasil

${ }^{3}$ Programa de Pós-graduação em Biotecnologia, Universidade Federal do Espírito Santo - UFES, Vitória, ES, Brasil

${ }^{4}$ Departamento de Medicina Veterinária, Centro de Ciências Agrárias e Engenharias, Universidade Federal do Espírito Santo - UFES, Alegre, ES, Brasil

${ }_{5}^{5}$ Laboratório de Patologia Animal, Departamento de Medicina Veterinária, Universidade Federal do Espírito Santo - UFES, Alegre, ES, Brasil

${ }^{6}$ Departamento de Parasitologia Animal, Instituto de Veterinária, Universidade Federal Rural do Rio de Janeiro - UFRRJ, Seropédica, RJ, Brasil
\end{abstract}

Received March 27, 2018

Accepted November 26, 2018

\begin{abstract}
Currently, albendazole is one of the most commonly used drugs because of its affordability. The objective was to evaluate the histopathology of Fasciola hepatica specimens. For this, the efficacy test was performed on sheep treated with albendazole at the dose recommended for $F$. hepatica, in which the helminths recovered at necropsy were counted and separated for histology. Spermatogenic cells from parasites recovered from treated and control sheep were examined by microscopy. The fecal egg-count reduction test revealed $97.06 \%$ efficacy of albendazole in the treatment of $F$. hepatica. Changes in testicular tubule cells started 48 hours after treatment and became evident within 72 hours, at which point it became difficult to identify cell types. Primary and secondary spermatogonia became increasingly rare and intercellular vacuolization was more evident. Signs of apoptosis, with pycnotic nuclei and evidence of keriorrexia were observed at all times. Cell debris was identified 96 hours after treatment. The results indicated that parasitic spermatogenesis was severely affected by albendazole and demonstrated the importance of the use of histopathology for the diagnosis of therapeutic efficacy in field strains.
\end{abstract}

Keywords: Fasciolosis, histopathology, treatment, albendazole.

\section{Resumo}

$\mathrm{Na}$ atualidade, o albendazol é uma das drogas mais usadas devido à sua acessibilidade econômica. O objetivo foi avaliar a histopatologia dos espécimes de Fasciola hepatica. Para isso, foi realizado o teste de eficácia em ovinos tratados com albendazol na dose recomendada para Fasciola hepatica, no qual os helmintos recuperados em necropsia foram contabilizados e separados para histologia. As células espermatogênicas de parasitas recuperados de ovinos tratados e controle foram examinadas por microscopia. O teste de redução de ovos por grama de fezes revelou $97,06 \%$ de eficácia do albendazol no tratamento de $F$. hepatica. As alteraçóes nas células dos túbulos testiculares iniciaram-se 48 horas após o tratamento e tornaram-se evidentes em 72 horas, altura em que tornou-se difícil identificar os tipos de células. As espermatogônias primárias e secundárias tornaram-se cada vez mais raras e a vacuolização intercelular foi mais evidente. Sinais de apoptose, com núcleos picnóticos e evidência de cariorrexia foram observados em todos os momentos. Os detritos celulares foram identificados 96 horas após o tratamento. Os resultados indicaram que a espermatogênese parasitária foi severamente afetada pelo albendazol e demonstrou a importância do uso da histopatologia para o diagnóstico de eficácia terapêutica em cepas de campo.

Palavras-chave: Fasciolose, histopatologia, tratamento, albendazol.

${ }^{*}$ Corresponding author: Isabella Vilhena Freire Martins. Departamento de

Medicina Veterinária, Centro de Ciências Agrárias e Engenharias, Universidade

Federal do Espírito Santo - UFES, Alto Universitário, s/n, Guararema,

CEP 29500-000, Alegre, ES, Brasil. e-mail: ivfmartins@gmail.com 


\section{Introduction}

An adequate association between property management and flock treatment schedules is necessary for the effective control of Fasciola hepatica (FAO, 1994). Currently, few drugs are available in Brazil for the treatment of animals infected with $F$. hepatica and most them already develop resistance to the field (ALVES \& MARTINS, 2013).

Among the drugs available for the control of $F$. hepatica, one of the most important chemical groupings is that of the benzimidazole group. Currently, the most effective of these agents is triclabendazole because its efficacy is not restricted to adult helminths and it also treats the immature forms. There are reports of $F$. hepatica populations resistant to triclabendazole, which includes parallel resistance to albendazole (MARTINEZVALLADARES et al., 2014).

When assessing the efficacy of, or resistance to, these drugs, it is important to consider the strain present in each region and even on each property. Studies related to the production, development, and/or elimination of helminth eggs in feces, the detection of antigens in feces, and the morphological and functional changes in the tegument and reproductive system of the parasite are essential for the proper demonstration of treatment results. These studies involve the collection and analysis of feces, the incubation of eggs in vitro, and scanning electron microscopy, transmission electron microscopy, or histopathology analysis.

According to Hanna (2015), histological techniques are useful not only for the triage of samples representative of helminths in field trials, which are performed to validate drug resistance tests, but also to test the efficacy of new products against known isolates resistant or sensitive to drugs.

Several studies have histologically evaluated $F$. hepatica samples obtained from sheep treated with triclabendazole (HANNA et al., 2010, 2012; TONER et al., 2011). However, no studies were found in the literature addressing $F$. hepatica obtained from sheep treated with albendazole.

The objective of this study was to determine the structural changes in $F$. hepatica specimens obtained from infected sheep treated with albendazole using optical microscopy.

\section{Materials and Methods}

Our study was carried out in the southern region of Espírito Santo State, a region with a predominantly humid and subtropical climate, and high annual precipitation (IBGE, 2008). Martins et al. (2012), characterized a study area with high temperatures but with relatively low slope, low precipitation, and low elevation, corresponding to periodically flooded grasslands or soils which promote water retention and, consequently, a higher risk of incidence of fasciolosis.

\section{Albendazole efficacy test}

Fourteen sheep, crossbreed, males and females, adults, with an average weight of $61 \mathrm{Kg}$, naturally infected with $F$. hepatica were selected for this study. The animals were confined in stalls with water and food ad libitum. Infection was confirmed through stool tests using the quantitative technique described by Foreyt (2005).

Seven sheep were treated orally with albendazole (VALBAZEN COBALTO $^{\circledR}$, PFIZER, NEW YORK, USA) at a dose of $10 \mathrm{mg} / \mathrm{kg}$ of live body weight (according to the manufacturer's recommendation) with the aid of a dosing gun for a total of $6 \mathrm{~mL}$ per animal. Seven sheep were kept as controls. Ten days after dosing, a new test was performed to verify the efficacy of the treatment used. The fecal egg-count reduction test (FECRT), that is, the effectiveness of the tested active principle, was performed using the formula described by Coles et al. (1992).

\section{Microscopic alterations}

Four sheep, crossbreed, females, adults, with an average weight of $56 \mathrm{Kg}$, naturally infected with $F$. hepatica were selected for this part of the study. Three sheep were treated with the same conditions described above and one was kept as a control. The animals were confined in stalls with water and food ad libitum.

The three treated animals were euthanized following the guidelines for the euthanasia of experimental animals set out by the Brazilian National Council for the Control of Animal Experimentation at 48, 72, and 96 hours post-treatment. Necropsies were performed immediately after euthanasia, and $F$. hepatica specimens were recovered from the bile ducts of the liver and gall bladder. The control animal was euthanized at 96 hours and F. hepatica samples were collected. All samples were sent in saline solution to the Laboratory of Animal Pathology, Veterinary Hospital, Federal University of Espírito Santo and were observed macroscopically to evaluate the integrity of the tegument and intestinal filling prior to processing to assess alterations in the tegument. The integrity of the integument was observed macroscopically, identifying whether there was any lesion in the integument and whether the parasite's motility was impaired. In addition, the intestinal filling was verified by the observation of the tonality, where dark tones indicated the presence of food.

Two $F$. hepatica specimens from each animal were selected from and placed between slides and were fixed in Bouin solution for 24 hours. After this period, the specimens were histologically processed following the methodology of Toner et al. (2011) with modifications, in which the specimens remained for 15 minutes in ethanol at $70^{\circ}$ G.L. Next, each specimen was cross-sectioned in the region that corresponded to the location of the reproductive system, which encompasses the right and left halves and the median plane. Cassettes containing the sections were washed in ethanol at $70^{\circ} \mathrm{G}$.L and placed in absolute ethanol for 1 hour. Then, the cassettes were transferred to another vessel containing absolute ethanol for one additional hour, changed to xylene at $37^{\circ} \mathrm{C}$ for 15 minutes, and finally xylene with paraffin (1:1) at $60{ }^{\circ} \mathrm{C}$ for 15 minutes prior to being embedded in paraffin blocks. Three-micrometer-thick cuts were made in a rotary microtome, and the sections were deposited onto slides and stained with hematoxylin-eosin in accordance with Luna (1968).

The slides were examined and the reproductive tract was photomicrographed using an Olympus ${ }^{\circledR}$ microscope with a Sony ${ }^{\circledR}$ 
camera at $10 \times$ and $40 \times$ magnification. Images were analyzed using the Micro image Analyzer ${ }^{\circledR}$ program.

\section{Declarations ethics approval}

The protocol titled "Validação de uma técnica de diagnóstico e avaliação da eficácia do albendazol no controle de Fasciola hepatica em ovinos" was approved on January 4, 2013 by the Commission for Ethics in the Use of Animals of the Foundation to Support Scientific and Technological Research of Federal Rural University of Rio de Janeiro.

\section{Results}

The FECRT revealed that albendazole is efficient in the treatment of $F$. hepatica infected sheep, where a reduction in egg count and efficacy of $97.06 \%$ could be observed (Table 1 ).

The parasites recovered from the necropsied animals at the time of 48, 72, 96 hours after treatment (Table 2). Two specimens of $F$. hepatica from the control group selected from each animal for histological analysis had macroscopically intact integument and incomplete intestinal contents. While the parasites obtained from treated animals also had macroscopically intact teguments; however, the intestinal contents showed variations in saturation with the passage of time after treatment.

The specimens retrieved from the control animal showed normal testicular morphology, with testicular cells at all stages of the spermatogenesis process being present. Primary and secondary spermatogonia were observed on the periphery of the testis tubules. In the interior of the tubules, it was possible to observe tertiary spermatogonia, spermatocytes and sperm.

Primary and secondary spermatogonia are generally characterized by a small rounded nucleus with condensed chromatin. These cells are located adjacent to the basement membrane of the tubules. Tertiary spermatogonia are larger, with less-dense nuclei and abundant cytoplasm. The primary spermatocytes have large, rounded nuclei and chromatin with different degrees of spiraling. They are located near the spermatogonia but are inside the tubule. Finally, the spermatozoa have the very visible characteristic appearance of cells with tails (Figure 1).

When analyzing the slides containing parasites recovered 48 hours after treatment, cellular rarefaction was noted in the testis tubules compared to the normal tubules, resulting in a larger space between cells, which may be indicative of cell death.

The cells observed were concentrated on the periphery of the tubules and in the central region, where tertiary spermatogonia

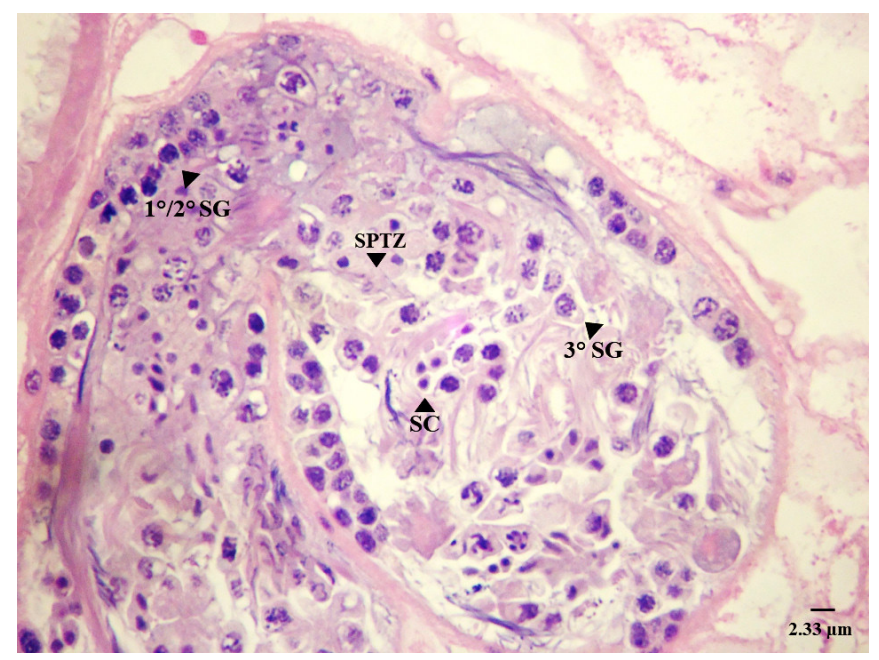

Figure 1. Testicular tubule of the F. hepatica from a control animal. SG: spermatogonia, SC: spermatocyte, SPTZ: spermatozoid. Objective 40x. Bar $=2.33 \mu \mathrm{m}$.

Table 1. Number of Fasciola hepatica eggs per gram of feces, per animal, and percentage of albendazole effectiveness in sheep.

\begin{tabular}{|c|c|c|c|c|c|c|}
\hline \multirow{2}{*}{ ID } & \multicolumn{2}{|c|}{ Control } & \multirow{2}{*}{ ID } & \multicolumn{2}{|c|}{ Treated (Albendazole) } & \multirow{2}{*}{ Efficacy } \\
\hline & EPG (Day 0) & EPG (Day 10) & & EPG (Day 0) & EPG (Day 10) & \\
\hline $001^{\mathrm{F}}$ & 30 & 50 & $007^{\mathrm{F}}$ & 50 & 1 & $97.06 \%$ \\
\hline $002^{\mathrm{F}}$ & 50 & 50 & $136^{\mathrm{M}}$ & 10 & 0 & \\
\hline $137^{\mathrm{F}}$ & 2 & 0 & $140^{\mathrm{F}}$ & 10 & 0 & \\
\hline $138^{\mathrm{M}}$ & 2 & 2 & $141^{\mathrm{M}}$ & 15 & 0 & \\
\hline $139^{\mathrm{M}}$ & 10 & 2 & $146^{\mathrm{F}}$ & 2 & 1 & \\
\hline $149^{\mathrm{M}}$ & 5 & 10 & $147^{\mathrm{F}}$ & 2 & 2 & \\
\hline $152^{\mathrm{M}}$ & 10 & 22 & $148^{\mathrm{M}}$ & 1 & 0 & \\
\hline Mean & 15.57 & 19.42 & Mean & 15.42 & 0.57 & \\
\hline
\end{tabular}

ID: identification of animal; EPG: eggs per gram; F: female; M: male.

Table 2. Number of Fasciola hepatica recovered in hepatic liver from sheep treated with albendazole at different times for microscopic evaluation.

\begin{tabular}{ccccc}
\hline ID & Groups & EPG & \multicolumn{2}{c}{ Number of Fasciola hepatica recovered } \\
\cline { 4 - 5 } & Treated +48h & 25 & Adults & 0 \\
$\mathbf{0 0 8}^{\mathrm{F}}$ & Treated $+72 \mathrm{~h}$ & 20 & 14 & 14 \\
$\mathbf{0 0 5}^{\mathrm{F}}$ & Treated $+96 \mathrm{~h}$ & 3 & 11 & 0 \\
$\mathbf{1 5 1}^{\mathrm{F}}$ & Control $+96 \mathrm{~h}$ & 360 & 243 & 82 \\
$\mathbf{0 0 2}^{\mathrm{F}}$ & & & \\
\hline
\end{tabular}

ID: identification of animal; EPG: eggs per gram; F: female. 
and primary spermatocytes are normally observed; these cell types were found in significantly reduced numbers.

Spermatogonia, which are normally in contact with the wall of the tubule, were found in reduced numbers and often exhibited vacuolated cytoplasm. Some of the nuclei of these cells showed signs of pyknosis and karyorrhexis, which are characteristics of apoptosis. Primary spermatocytes showed cytoplasmic eosinophilia and nuclear signs of cellular apoptosis, such as fragmentation and nuclear pyknosis and karyorrhexis. A reduced number of spermatozoa was noted in relation to the control group (Figure 2).

When analyzing testicular cells 72 hours after treatment, we noted that cellular rarefaction of the testis tubules was increased

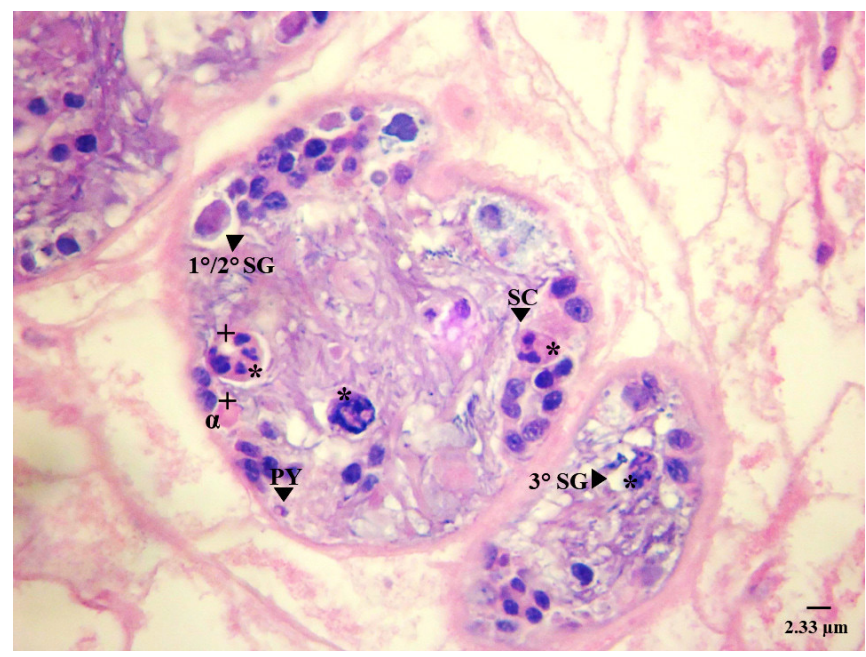

Figure 2. Testicular tubule of the $F$. hepatica from an animal treated with albendazole and euthanized 48hours after treatment, demonstrating cell rarefaction, signs of apoptosis $(\alpha)$, pyknosis (PY), karyorrhexis $\left({ }^{*}\right)$ and cytoplasmic eosinophilia (+). SG: spermatogonia, SC: spermatocyte. Objective 40x. Bar $=2.33 \mu \mathrm{m}$.

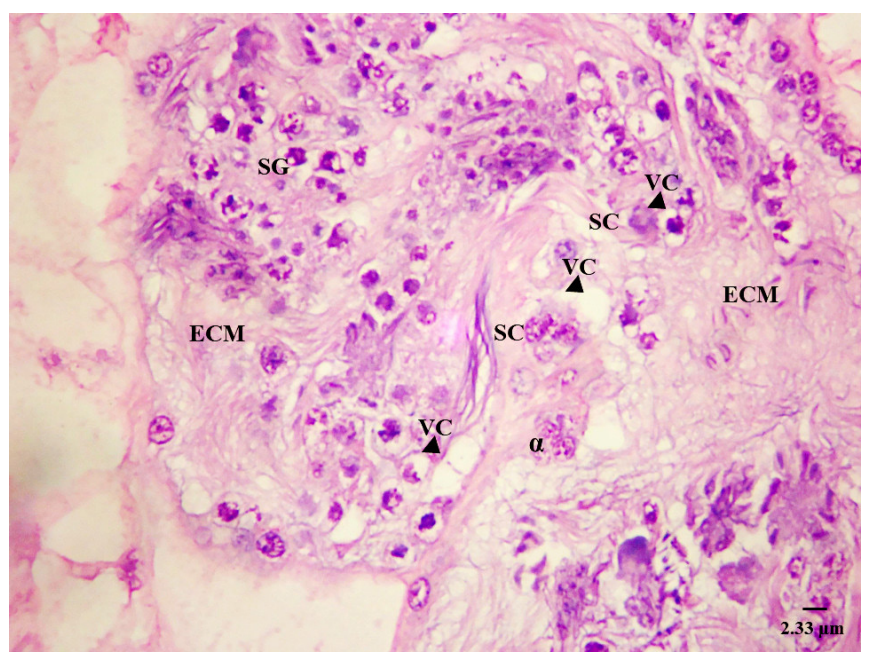

Figure 3. Testicular tubule of the $F$. hepatica from an animal treated with albendazole and euthanized 72 hours after treatment, with vacuolization (VC), cellular apoptosis $(\alpha)$ and amorphous eosinophilic cellular material (ECM). SG: spermatogonia, SC: spermatocyte. Objective 40x. Bar $=2.33 \mu \mathrm{m}$. in relation to the specimens observed at 48 hours and had the same intense vacuolization.

The primary and secondary spermatogonia in the periphery of the tubules showed cytoplasmic vacuolization, including signs of cellular apoptosis that were more widespread among the cells. These spermatogonia had become indistinguishable from tertiary spermatogonia. The vacuolization of cells extended towards the center of the tubules, characterizing a cellular disorganization with many spaces between cells. The spermatocytes showed signs of cellular apoptosis, and a significant amount of amorphous eosinophilic cellular material was noted within the tubules (Figure 3).

At 96 hours post-treatment, the spaces between cells had increased, and the cells that remained in the region had become highly vacuolated. There was no production of new stem cells, and spermatozoa were rarely observed. In the cells that remained in the center of the tubules, signs of cytoplasmic eosinophilia and apoptosis were observed, as well as pyknotic nuclei. Cellular debris was observed between the remaining cells (Figure 4).

\section{Discussion}

\section{Albendazole efficacy}

In a study with cattle in the same region by Leão et al. (2012) observed that the efficacy of albendazole was 19.64 and $26.53 \%$ at 7 and 21 days after treatment and of the albendazole sulfoxide was $71.56 \%$ and $78.65 \%$ at 7 to 14 days after treatment. Nevertheless, the FECRT revealed that albendazole is effective in the treatment of sheep naturally infected with $F$. hepatica, with efficacy of $97.06 \%$. According to Wood et al. (1995), the efficacy of a product, for nematodes, trematodes and cestodes, should be expressed against each genus/species (larvae/adults) as: highly effective (over 98\%), effective (90-98\%), moderately effective (80-89\%) or insufficiently active (less than $80 \%$ ).

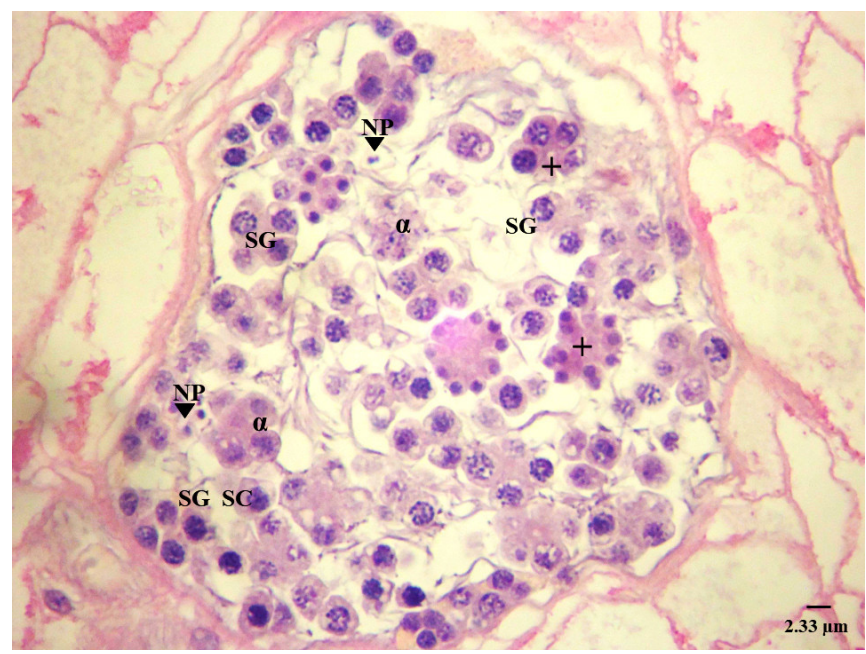

Figure 4. Testicular tubule of the F. hepatica from an animal treated with albendazole and euthanized 96 hours after treatment, with signs of cytoplasmic eosinophilia $(+)$, apoptosis $(\alpha)$ and nuclear pyknosis (NP). SG: spermatogonia, SC: spermatocyte. Objective $40 \mathrm{x}$. Bar $=2.33 \mu \mathrm{m}$. 
The discrepancy of the results for the same region can be explained by the species involved, in which albendazole may be efficient due to the characteristics of each species. In addition, Leão et al. (2012) used only the EPG technique and in the present work the eggs/parasites were recovered during the necropsy of the sheep. More, this difference can be probably associated with the retention of eggs of $F$. hepatica in the gallbladder of the animal, requiring distinct times for the complete elimination of the trematode eggs, in some cases being necessary more than 21 days.

Moreover, according to Fairweather (2011) reports of fasciolicide resistance constantly appear in publications, but do not necessarily represent true cases of resistance. Several factors contribute to ineffectiveness such as incorrect dose, product failure, reduction of metabolism by liver injury among others.

It is noteworthy that the indication for albendazole for treatment against $F$. hepatica is $10 \mathrm{mg} / \mathrm{kg}$, and its efficacy in flukes above 10 weeks of age ranges from 91 to $99 \%$ (FAO, 1994).

\section{Microscopic alterations}

The microscopic findings confirmed that the parasitic strain from the area evaluated demonstrated sensitivity to treatment with albendazole because morphological changes in spermatogenic cells were observed over time. These results are consistent with the study conducted by Hanna et al. (2010), who reported that strains known to be drug resistant did not show morphological alterations after treatment with triclabendazole, whereas strains known to be drug sensitive did show such alterations. Additionally, the authors demonstrated the importance of using histological techniques in field studies to validate drug resistance or to test the efficacy of new or sensitive drugs.

The male reproductive system of $F$. hepatica was evaluated in the present study to demonstrate the effects of albendazole in this region and to show that the parasite could be used as a model of study for drug action. The testes of $F$. hepatica have a high metabolic demand to support the production of the large number of spermatozoa necessary to maintain the output of the large number of eggs; therefore, they are sensitive to the action of drugs (HAPPICH \& BORAY, 1969).

Albendazole, belonging to the class of benzimidazoles, acts by inhibiting the polymerization of helmintic $\beta$-tubulin, thus interfering with microtubule-dependent functions, such as in capturing glucose (RANG et al., 2016).

Another important function dependent on microtubes is spermatogenesis, which involves high mitotic and meiotic rates that are related to microtubules as part of the spindle apparatus that helps separate the chromosomes. Additionally, the spindle apparatus is involved in changes in cell morphology during cell differentiation because these changes are supported by microtubules (STITT \& FAIRWEATHER, 1990).

Albendazole also acts to inhibit the fumarate reductase enzyme, which culminates in the reduction of ATP synthesis and the stoppage of parasite metabolism, besides making eggs hatching unviable. The action of the drug is observed for a period of 48 hours from the administration and may be increased according to the dose used (RANG et al., 2016). This finding explains the changes observed during the cell differentiation process over the evaluation period and confirms the mode of action of albendazole identified in this study.

The morphological characteristics observed for the control animal are consistent with those observed by Hanna et al. (2008, 2010), McConville et al. (2010), and Toner et al. (2011) for F. hepatica specimens not exposed to anthelmintic. Spermatogonia and primary spermatocytes were observed to occupy the entire region of the testis tubule, thereby ensuring the production of viable sperm and, consequently, F. hepatica eggs.

In the present study, it was possible to observe changes in the morphology of spermatogenic cells starting at 48 hours. These alterations became increasingly more evident by 72 and 96 hours post-treatment, which agrees with the findings of Toner et al. (2011). These authors reported the same changes in the testis tubules and differed only in the drug tested (triclabendazole), demonstrating that the mechanism of adulticidal action of albendazole was effective in the present field strain, similar to triclabendazole in the study conducted by Toner et al. (2011).

According to McConville et al. (2010), the vacuolization that was initially observed in the periphery of the tubules and later throughout the tubule might be related to a loss of support cells. In the present study, this vacuolization was observed starting at 48 hours post-treatment and became more obvious in the evaluation at 72 hours, as was also observed by McConville et al. (2010).

The eosinophilic cellular material that was primarily observed at 72 hours post-treatment was related to the abnormal development and characteristics of apoptosis of the spermatogonia and spermatocytes by the tubules. In addition to nuclear fragmentation and loss, the cytoplasm became more eosinophilic until cell death occurred. These findings are similar to those reported by Hanna et al. (2008, 2010) and Toner et al. (2011), who used triclabendazole, and McConville et al. (2010), who used an Alpha compound; these studies also associated these characteristics with the loss of spermatogenic cells and spermatocytes.

At 48 hours post-treatment, it was possible to observe the first cellular alterations in the seminiferous tubes, with the loss of primary and secondary spermatogonia and support cells. This ensures no further development of tertiary spermatogonia or spermatocytes and, consequently, spermatozoa. The cell death and apoptotic characteristics became more evident by 72 hours and were observed in many cells with nuclear pyknosis and karyorrhexis. This result demonstrates that some cells are still undergoing development prior to this time point, although many have undergone nuclear and cytoplasmic changes resulting in subsequent cell death.

Hanna et al. (2012) reported that morphological changes in the reproductive tract of $F$. hepatica began 24 hours after administration of triclabendazole. This finding could not be confirmed in the case of albendazole because the first time point evaluated was at 48 hours. A study conducted by Buchanan et al. (2003) using albendazole for the in vitro treatment of adult $F$. hepatica specimens showed internal and external cutaneous changes at 24 hours post-treatment, but the authors did not evaluate changes in spermatogenic cells. McConville et al. (2010) performed in vivo treatment with an Alpha compound and observed cutaneous alterations at the first evaluation time point, 48 hours post-treatment. 
In the present study, cutaneous alterations were only observed macroscopically, which did not identify details of vesiculation and deformations on the surfaces of the parasites. However, the intestinal contents of the parasites were full in the control animal, with different degrees of saturation over the course of the evaluation. This result may indicate a decrease or halt in the activities of the parasite due to the action of benzimidazole, which inhibits microtubule formation and interferes with the absorption of nutrients (LACEY, 1988; JASMER et al., 2000), leading to death of the parasite.

Similar to the observations by McConville et al. (2010) (using an Alpha compound for the treatment of animals), in the present study, severe degenerative changes and difficulty in identifying individual cell types was observed at the 72-hour evaluation. This same result was observed by Toner et al. (2011) in a study using triclabendazole. These findings confirmed the sensitivity of the testes to the action of the drugs, with an interruption in cellular development that occurs to a greater extent compared to that of other reproductive organs, such as the ovary, uterus, and vitellarium (HANNA et al., 2006).

A reduction in spermatozoid production was observed over the course of the evaluation, primarily due to the loss of cells. According to Stitt \& Fairweather (1992), the remaining spermatozoa may appear abnormal due to a failure in the organization of the microtubules of their axonemes, which may have also occurred in the present study.

The changes observed in the testes suggest that it was the action of the drug and not a side effect that caused deterioration of the parasite. This fact has a direct impact on egg production: fewer eggs are produced, there may be abnormal production of eggs, and some eggs may not embryonate and/or hatch in the environment. According to Alvarez et al. (2009), albendazole has an excellent ovicidal action against $F$. hepatica.

Any flaw in egg production affects the epidemiological cycle of the induced disease because it halts or decreases pasture contamination. Hanna et al. (2006) also reported that it was important to perform treatment when all parasites reached maturity to ensure actual interference in egg production when using an adulticidal such as albendazole. However, Scarcella et al. (2011) reported that any surviving parasites might stimulate the host to mount an immune response to counter the infection.

Histology can be used to test the efficacy of products on strains known to be susceptible or resistant to certain drugs through the observation of histopathological changes induced by the drugs in the reproductive structures of trematodes (HANNA, 2015). The present study demonstrated the feasibility of the use of an evaluation tool as an examination via histological analysis of adult F. hepatica specimens from sheep treated with albendazole. We used spermatogenesis as a sensitivity indicator of activity of the benzimidazole class of drugs.

The use of histology in this study was intended to clarify the action of the drug on the parasite. The advantage of this diagnostic route over the EPG measurement is that if the animal has only young parasitized animals there will be no presence of eggs in the faeces, in addition to the fact that the egg release in the faeces can be influenced by the low sensitivity of the technique and by the intermittent release of eggs stored in the gallbladder and may present false negative or false positive results. It is also worth mentioning that the use of parasite histology would be an important tool in efficacy studies, since the slaughter of animals in the routine of the farm to verify the action of albendazole on the parasites by histology would be economically unfeasible.

\section{Conclusion}

Morphological changes were present in the cells of the testis tubules of $F$. hepatica from naturally infected sheep treated with albendazole. The results showed the interference by albendazole of the production of spermatozoa and, consequently, the production of viable eggs by the parasite. The histological evaluation presented as an important tool for the knowledge of the antihelmintic action on trematoda, emphasizing the inclusion of this methodology in efficacy studies with necropsy, since the animals may also be parasitized with young forms that do not release eggs. This study further helps in understanding the drug's action on parasites.

\section{References}

Alvarez L, Moreno G, Moreno L, Ceballos L, Shaw L, Fairweather I, et al. Comparative assessment of albendazole and triclabendazole ovicidal activity on Fasciola hepatica eggs. Vet Parasitol 2009; 164(2-4): 211-216. http:// dx.doi.org/10.1016/j.vetpar.2009.05.014. PMid:19560276.

Alves DP, Martins IVF. Atualizaçóes no controle parasitário da fasciolíase em bovinos. Enc Biosfera 2013; 9(16): 323-351.

Buchanan JF, Fairweather I, Brenna GP, Trudgett A, Hoey EM. Fasciola hepatica: surface and internal tegumental changes induced by treatment in vitro with the sulphoxide metabolite of albendazole ('Valbazen'). Parasitology 2003; 126(2): 141-153. http://dx.doi.org/10.1017/S0031182002002664. PMid:12636352.

Coles GC, Bauer C, Borgsteede FHM, Geerts S, Klei TR, Taylor MA, et al. World Association for the Advancement of Veterinary Parasitology (W. A. A. V. P.) methods for the detection of anthelmintic resistance in nematodes of veterinary importance. Vet Parasitol 1992; 44(1-2): 35-44. http://dx.doi.org/10.1016/0304-4017(92)90141-U. PMid:1441190.

Fairweather I. Reducing the future threat from (liver) fluke: realistic prospect or quixotic fantasy? Vet Parasitol 2011; 180(1-2): 133-143. http://dx.doi.org/10.1016/j.vetpar.2011.05.034. PMid:21703766.

Food and Agriculture Organization of the United Nations - FAO. Enfermedades de los animales domésticos causadas por distomas. Roma: FAO; $1994.55 \mathrm{p}$

Foreyt WJ. Parasitologia veterinária: manual de referência (5th ed.). São Paulo: Roca; 2005.

Hanna REB, Cromie L, Taylor SM, Couper A. The effect of a parenteral ivermectin/closantel injection on the growth and reproductive development of early immature Fasciola hepatica in cattle. Vet Parasitol 2006; 142(1-2): 78-90. http://dx.doi.org/10.1016/j.vetpar.2006.06.025. PMid:16901648.

Hanna REB, Edgar H, Moffett D, McConnell S, Fairweather I, Brennan GP, et al. Fasciola hepatica: histology of the testis in egg-producing adults of several laboratory-maintained isolates of flukes grown to maturity in cattle and sheep and in flukes from naturally infected hosts. Vet Parasitol 2008; 157(3-4): 222-234. http://dx.doi.org/10.1016/j.vetpar.2008.07.022. PMid:18774647. 
Hanna REB, Edgar HWJ, McConnell S, Toner E, McConville M, Brennan GP, et al. Fasciola hepatica: histological changes in the reproductive structures of triclabendazole (TCBZ)-sensitive and TCBZ-resistant flukes after treatment in vivo with TCBZ and the related benzimidazole derivative, Compound Alpha. Vet Parasitol 2010; 168(3-4): 240-254. http://dx.doi. org/10.1016/j.vetpar.2009.11.014. PMid:20053501.

Hanna REB, Scarcella S, Solana H, McConnell S, Fairweather I. Early onset of changes to the reproductive system of Fasciola hepatica following in vivo treatment with triclabendazole. Vet Parasitol 2012; 184(2-4): 341347. http://dx.doi.org/10.1016/j.vetpar.2011.08.023. PMid:21944196.

Hanna REB. Fasciola hepatica: Histology of the reproductive organs and differential effects of triclabendazole on drug-sensitive and drug-resistant fluke isolates and on flukes from selected field cases. Pathogens 2015; 4(3): 431-456. http://dx.doi.org/10.3390/pathogens4030431. PMid:26131614.

Happich FA, Boray JC. Quantitative diagnosis of chronic fasciolosis. 1. Comparative studies on quantitative faecal examinations for chronic Fasciola hepatica infection in sheep. Aust Vet J 1969; 45(7): 326-328. http://dx.doi.org/10.1111/j.1751-0813.1969.tb05009.x. PMid:5817298.

Instituto Brasileiro de Geografia e Estatística - IBGE. Produção Pecuária Municipal [online] 2008. [cited 2017 Sept 17]. Available from: http:// www.ibge.gov.br/home/estatistica/economia/ppm/2008/defaulttabzip.shtm

Jasmer DP, Yao C, Rehman A, Johnson S. Multiple lethal effects induced by a benzimidazole anthelminticinthe anterior intestine of the nematode Haemonchus contortus. Mol Biochem Parasitol 2000; 105(1): 81-90. http:// dx.doi.org/10.1016/S0166-6851(99)00169-3. PMid:10613701.

Lacey E. The role of the cytoskeletal protein, tubulin, in the mode of action and mechanism of drug resistance to benzimidazoles. Int J Parasitol 1988; 18(7): 885-936. http://dx.doi.org/10.1016/0020-7519(88)901750. PMid:3066771.

Leão AGC, Montalvão FA, Sobreira RR, Carneiro MB, Fazio PI Jr, Tavares PV, et al. Eficácia do albendazole, sulfóxido de albendazole e do clorsulon no controle da fasciolose em bovinos leiteiros. Rev Bras Med Vet 2012; 34(Suppl 1): 11-14.

Luna LG. Manual of histologic staining methods of the armed forces institute of pathology. 3rd ed. New York: McGraw-Hill; 1968.
Martínez-Valladares M, Cordero-Pérez C, Rojo-Vázquez FA. Efficacy of an anthelmintic combination in sheep infected with Fasciola hepatica resistant to albendazole and clorsulon. Exp Parasitol 2014; 136: 59-62. http://dx.doi.org/10.1016/j.exppara.2013.10.010. PMid:24211419.

Martins IVF, Avelar BR, Pereira MJS, Fonseca AH. Application of a geographical information system approach for risk analysis of fascioliasis in southern Espírito Santo state, Brazil. Geospat Health 2012; 6(3): S87-S93. http://dx.doi.org/10.4081/gh.2012.126. PMid:23032288.

McConville M, Hanna REB, Brennan GP, McCoy M, Edgar HWJ, McConnell S, et al. Fasciola hepatica: disruption of spermatogenesis by the fasciolicide compound alpha. Parasitol Res 2010; 106(2): 311-323. http://dx.doi.org/10.1007/s00436-009-1649-9. PMid:19921260.

Rang R, Ritter JM, Flower RJ, Henderson G. Farmacologia. 8 ed. Rio de Janeiro: Elsevier; 2016.

Scarcella S, Fiel C, Guzman M, Alzola R, Felipe A, Hanna REB, et al. Reproductive disruption in Fasciola hepatica associated with incomplete efficacy of a new experimental formulation of triclabendazole. Vet Parasitol 2011; 176(2-3): 157-164. http://dx.doi.org/10.1016/j.vetpar.2010.11.009. PMid:21167645.

Stitt AW, Fairweather I. Spermatogenesis and the fine structure of the mature spermatozoon of the live fluke, Fasciola hepatica (Trematoda: Digenea). Parasitology 1990; 101(Pt 3): 395-407. http://dx.doi.org/10.1017/ S0031182000060595. PMid:2092295.

Stitt AW, Fairweather I. Spermatogenesis in Fasciola hepatica: an ultrastructural comparison of the effects of the anthelmintic, triclabendazole ("Fasinex") and the microtubule inhibitor, tubulozole. Invertebr Reprod Dev 1992; 22(1-3): 139-150. http://dx.doi.org/10.1080/07924259.1992.9672266.

Toner E, Brennan GP, Hanna REB, Edgar HWJ, Fairweather I. Fasciola hepatica: time-dependent disruption of spermatogenesis following in vivo treatment with triclabendazole. Parasitol Res 2011; 109(4): 1035-1043. http://dx.doi.org/10.1007/s00436-011-2341-4. PMid:21541756.

Wood IB, Amaral NK, Bairden K, Ducan JL, Kassai T, Malone JB, et al. World Association for the Advancement of Veterinary Parasitology (W.A.A.V.P.) second edition of guidelines for evaluating the efficacy of anthelmintics in ruminants (bovine, ovine, caprine). Vet Parasitol 1995; 58(3): 181-213. PMID: 7571325. 